\title{
Optimizing SARS-CoV-2 molecular diagnostic using N gene target: insights
}

\section{about reinfection}

\section{Raphael Contelli Klein ${ }^{*}$, Mary Hellen Fabres Klein ${ }^{1}$, Larissa Gomes Barbosa ${ }^{1}$, Lívia Vasconcelos Gonzaga Knnup ${ }^{1}$, Larissa Paola Rodrigues Venâncio ${ }^{1 *}$, Jonilson Berlink Lima $^{1^{*}}$ and Théo Araújo-Santos ${ }^{1 * \#}$}

${ }^{1}$ Núcleo de Estudos de Agentes Infecciosos e Vetores (NAIVE), Centro das Ciências Biológicas e da Saúde, Universidade Federal do Oeste da Bahia (UFOB), Barreiras, Bahia, Brasil.

* These authors contributed equally to this work.

\# Corresponding authors: Raphael Contelli Klein, PhD; Théo Araújo-Santos, PhD, Laboratório de Agentes e Infecciosos e Vetores (LAIVE), Centro das Ciências Biológicas e da Saúde, Universidade Federal do Oeste da Bahia. Rua da Prainha, 1326, Morada Nobre. Barreiras, Bahia, Brasil. Zip code: 47810-047. E-mail: raphael.klein@ufob.edu.br; E-mail: theo.santos@ufob.edu.br, Phone number: +55 77 3614-3218. 


\begin{abstract}
Introduction: Molecular diagnosis of SARS-CoV-2 is a huge challenge to many countries around the world. The cost of tests to check infected people is inaccessible since specialized teams and equipment are not disposable in remote locations. Herein, we compared the fitness of two primers sets to the SARS-CoV-2 $\mathrm{N}$ gene in the molecular diagnosis of COVID-19.
\end{abstract}

Materials and Methods: The 1029 patient samples were tested to presense/abscence molecular test using in house US CDC protocol. We compared the fitness of two primers sets to two different regions of $\mathrm{N}$ gene targets.

Results: Both targets, N1 and N2 displayed similar fitness during testing with no differences between $\mathrm{Ct}$ or measurable viral genome copies. In addition, we verified security ranges $\mathrm{Cts}$ related to positive diagnostic with $\mathrm{Ct}$ above 35 value failuring in $66,6 \%$ after retesting of samples.

Main conclusion: Our data suggest that it is secure to use just one primer set to the $\mathrm{N}$ gene to identify SARS-CoV-2 in samples and the labs should be careful to set positive samples in high $\mathrm{Ct}$ values using high cutoffs.

\title{
Keywords: Diagnostic, SARS-CoV-2, COVID-19, N gene, Reinfection
}

Sponsorship: Associação Baiana de Produtores de Algodão (ABAPA); Associação Baiana de Agricultores Irrigantes da Bahia (AIBA); Fundação de Amparo à Pesquisa do Estado da Bahia (FAPESB) (Grant Number: \#1381/2020); FINEP (Grant Number: \#0418000600); CNPq; CAPES, MEC, MCTIC. 


\section{Introduction}

Demands of molecular diagnosis to testing COVID-19 are fast growing around the world and costs and efficiency of the RT-PCR technique has been in check. In this context, different RT-PCR kits are used to identify SARS-CoV-2 virus in patients' samples are now available, using just one or multiple gene targets '(Pizzol et al. 2020, Mathuria et al. 2020).

After six months in the covid-19 pandemic, Brazil is between major countries affected by disease (Hallal et al. 2020). Genome vigilance of the virus is now occurring and variants of the virus genome are disposable to genomic banks permitting check of the virus specificity of the disposable tests (Candido et al. 2020). Some studies are comparing sensitivity and specificity of different sets of probes/primers against different gene targets of the SARS-CoV-2. In this context, the conserved nucleocapsid protein gene $(\mathrm{N})$ is the major target present in the disposable tests (Pizzol et al. 2020) and US CDC test includes two sets of primers with good sensitivity to virus detection (Etievant et al. 2020). In addition, recent work demonstrates some mutation in the forward primer to $\mathrm{N}$ gene target in Chinese CDC test, suggesting US CDC test can be more appropriate to Brazilian testing (Candido et al. 2020).

In this article, we compared the fitness between both commercial $\mathrm{N}$ gene targets present in the US CDC panel to SARS-CoV-2 and we identified similar results using both targets. In addition, we verified that high $\mathrm{Ct}$ value in patient samples presents low reproducibility, suggesting that this range of $\mathrm{Ct}$ value can contribute to misinterpretation in the test results. 


\section{Materials and Methods}

\section{Clinical Samples}

Nasopharyngeal, nasal and oropharyngeal swabs and sputum samples $(n=1029)$ collected during May and June of 2020 were obtained after SARS-CoV-2 detection in the Laboratory of Vectors and Infection Disease. Residual samples were de-identified samples and considered non-human subjects of the research. These samples were used to test the fitness profile of the US CDC 2019-nCoV_N1 and 2019-nCoV_N2 primerprobe sets as described in the following sections.

\section{RNA isolation}

Sputum and Swabs obtained from patients reporting covid-19-like synmptoms were processed to RT-qPCR SARS-CoV-2 detection. In brief, RNA isolation of samples was extracted using commercial kits following supplier's instructions, such as PureLink® Viral RNA/DNA Mini Kit (ThermoScientific), Cellco (Cellco Biotec) and Biogene (Quibasa) and RNAs were resuspended in $60 \mu \mathrm{L}$ of RNase-free water (GIBCO).

\section{RT-qPCR}

Quantitative Real-time PCR analysis was performed on QuantStudio 5 Real-Time PCR system (ThermoScientific, USA) using the primer set from 2019-nCOV RUO kit (IDT Coralville, IA). The PCR reaction mixture consisted of TaqMan Fast Virus 1-Step Master Mix (ThermoScientific), $0.75 \mu \mathrm{L}$ of primers and $2.5 \mu \mathrm{L}$ of RNA in a final volume of $10 \mu \mathrm{L}$ reaction. Cycling conditions were $50^{\circ} \mathrm{C}$ for $5 \mathrm{~min}$ and $95^{\circ} \mathrm{C}$ for 20 seconds, followed by 45 cycles at $95^{\circ} \mathrm{C}$ for 15 seconds and $58^{\circ} \mathrm{C}$ for $1 \mathrm{~min}$. Alternatively, we used KAPA PROBE FAST qPCR Master Mix (2X) Kit (Sigma- 
Aldrich), $0.75 \mu \mathrm{L}$ of primers and $2.5 \mu \mathrm{L}$ of RNA in a final volume of $10 \mu \mathrm{L}$ reaction.

Cycling conditions were $42^{\circ} \mathrm{C}$ for $5 \mathrm{~min}$ and $95^{\circ} \mathrm{C}$ for 3 minutes, followed by 45 cycles at $95^{\circ} \mathrm{C}$ for 5 seconds and $60^{\circ} \mathrm{C}$ for 1 minute. RNAse $\mathrm{P}$ was used as a sample control. The primers and concentrations used in the experiment were as follows: $500 \mathrm{nM} \mathrm{N1}$ : Forward: 5'-GACCCCAAAATCAGCGAAAT-3'; 500 nM N1: Reverse: 5'TCTGGTTACTGCCAGTTGAATCTG-3'; 125 nM N1-Probe FAMACCCCGCATtACGTTTGGTGGACC-NFQ-MGB; 500 nM N2: Forward: 5'TTACAAACATTGGCCGCAAA-3'; $500 \quad$ nM $\quad$ N2: $\quad$ Reverse: $\quad 5^{\prime}-$ GCGCGACATTCCGAAGAA- $\quad 3^{\prime} \quad$ and $125 \quad \mathrm{nM} \quad$ N2-Probe FAMACAATTTGCCCCCAGCGCTTCAG-NFQ-MGB (“Centers for Disease Control and Prevention. 2019-novel coronavirus (2019-nCoV) real-time RT-PCR primer and probe information" 2020). Specificity of the PCR products of N1 and N2 amplification were confirmed by polyacrylamide gel electrophoresis with silver stain.

\section{Statistical analysis}

Descriptive statistics were performed to determine the relative frequencies for categorical variables, as well as to obtain medians and their respective standard error values for continuous variables. Linear regression was built to compare N1 and N2 linearity profiles between both two targets to $\mathrm{Ct}$ value in all samples used in this study. A Receiver Operator Characteristics (ROC) curve analysis was performed to assess the sensibility and specificity of $\mathrm{Ct}$ value in a subset of samples. All data was analyzed using GraphPad Prism 5.0 (GraphPad Software Inc).

\section{Ethic statement}

The Research Ethics Committee of UFOB approved this study in 2020 (license number: 30629520.6.0000.0008). All clinical investigations were conducted according to the Declaration of Helsinki. 


\section{Results}

\section{No differences between $\mathrm{N} 1$ and $\mathrm{N} 2$ primers set fitness in the SARS-CoV-2 detection}

Several tests use just one set of primers to detect SARS-CoV-2 (Mathuria et al. 2020). The efficiency or increment of different targets in the detection of SARS-CoV-2 was poorly addressed. Herein, we evaluate fitness of $\mathrm{N}$ gene targets present in UCDC test diagnosis in 1029 population naso and oropharyngeal swabs or sputum samples. We verified N1 and N2 primers sets displayed similar Ct values for each sample (Figure 1). In order to verify the fitness in each $\mathrm{Ct}$ value range, we quantify the frequencies of results between $\mathrm{N} 1$ and $\mathrm{N} 2$ primers sets. We verify no differences of $\mathrm{Ct}$ value failure to detect viral RNA between both N1 and N2 primers sets (table 1). This data suggests just one primer set could be used to test patients with SARS-CoV-2 infection potentially reducing costs during molecular testing without diminish efficiency in the diagnosis accuracy.

\section{Accuracy of N gene target in SARS-CoV-2 detection}

The major challenge during presence/absence testing in molecular diagnosis is determinate the cut offs of testing. In this work, we verify using commercial templates of $\mathrm{N}$ gene the LoD and Cut offs of each $\mathrm{N} 1$ and $\mathrm{N} 2$ primers sets (supplementary figure 1). Both $\mathrm{N}$ gene targets were able to detect 5 genome copies (GC) per microliter of reaction with $\mathrm{Ct}$ value with $\mathrm{N} 1(34,28 \pm 0,6841)$ and $\mathrm{N} 2(34,18 \pm 0,5382)$. In recent work, mock group usage shows high $\mathrm{Ct}$ values during US CDC N molecular test, suggesting the importance of establishment of different cut offs that are suggested by standard protocols that recommend $40 \mathrm{Ct}$ value (Liu et al. 2020). Herein, we verified the 
reproducibility of high $\mathrm{Ct}$ values in patient samples using $\mathrm{N} 1$ and $\mathrm{N} 2 \mathrm{US}$ CDC primer sets (figure 2A). The use of many targets is justified by frequency of alteration in the viral genomes that can reduce the capacity of primer sets to detect the virus, but at same way is responsible to need more sophisticated apparatus to do diagnosis (Liu et al. 2020). We detect no mutation in $\mathrm{N}$ gene in the Latin American genome sequences of SARS-CoV-2 in the regions targets of US CDC primers set (supplementary figure 2). In addition, we identified nonspecific amplification using both primers set (figure 2B-C), which can be explained by annealing primers in different human genome regions (supplementary figure 2). Our data suggest that traditional PCR method and acrylamide gels can alternatively be used in remote locals with poor access to molecular tools.

\section{High Ct value has low predictive value to diagnosis}

In order to verify the specificity of the US CDC test, we evaluated samples from the same patient that were collected between 2 and 6 days after the first exam and we found that only $32 \%$ of the samples were negative, maintained the $\mathrm{Ct}$ value and another $33 \%$ reduced the $\mathrm{Ct}$ value (figure $3 \mathrm{~A}$ ). The ROC curve analysis for patients with $\mathrm{Ct}$ above 33 that were doubly positive revealed a low sensitivity (value) and specificity of the test (value) in samples with $\mathrm{Ct}$ above 33 (figure 3B). Thus, our data suggest that samples tested with $\mathrm{Ct}$ close to the detection limit have a low predictive value and should not be considered for diagnosis before collecting a new sample and performing a second confirmatory test.

\section{Discussion}

Analysis of the performance of tests for the detection of the SARS-CoV-2 virus has been carried out worldwide (Liu et al. 2020, Vogels et al. 2020)'. The performance of 
primers and probe sets for virus detection has been evaluated, but there are still few studies that assess the sensitivity and specificity in the critical range of detection of the RT-PCR technique (Mathuria et al. 2020). Among the most sensitive primer and probe sets are those for target $\mathrm{N}$ available by the US CDC (Vogels et al. 2020, Etievant et al. 2020)'. In this study, we evaluated the performance of the two sets of primers and probes used by the $\mathrm{CDC}$ and identified that both presented the same diagnostic performance, suggesting that only one of the targets could be used in the molecular diagnosis of COVID-19, as with other tests that use just one molecular target reducing costs (Pizzol et al. 2020, Mathuria et al. 2020). Liu et al. 2020 evaluated the performance of primer and probes sets from different RT-PCR diagnostic kits for COVID-19, finding results similar to those of our study (Liu et al. 2020). Here, we assessed the performance of the US CDC primer set on sputum and swabs patient samples and noted a similar performance between the two N1 and N2 targets for virus detection. Some studies have compared the sensitivity between specimens for the detection of SARS-CoV-2 and identified that saliva samples may have a similar or superior sensitivity to swab samples (Güçlü et al. 2020, Wyllie et al. 2020).

The RT-qPCR is the gold standard technique for detecting the SARS-CoV-2 virus and it has been used to validate alternative diagnostic methods for COVID-19 (Pizzol et al. 2020, Mathuria et al. 2020, Ai et al. 2020). However, data that assess the sensitivity and specificity of the technique for the higher $\mathrm{Ct}$ ranges are still scarce (Mathuria et al. 2020). In this sense, a study evaluated the $\mathrm{Ct}$ value of health workers who underwent two tests and found an increase in the $\mathrm{Ct}$ value in an interval of 21 days between exams (Cariani et al. 2020). Most commercial diagnostic tests recommend that $\mathrm{Ct}$ values below 40 be considered as the cutoff point for a positive diagnosis for coronavirus (Liu et al. 2020, Vogels et al. 2020, on behalf of the SARS-CoV-2 Foch Hospital study group et 
al. 2020). However, studies that evaluated the detection limit, as well as, our study have shown a low predictive value of RT-qPCR in samples with $\mathrm{Ct}$ above 35 using the US CDC protocol (Liu et al. 2020, Vogels et al. 2020). In this study, we found that patients with $\mathrm{Ct}$ samples above 33, when retested in a short period of time, may have the test result drastically altered, suggesting that high $\mathrm{Ct}$ values have a low positive predictive value. Due to the COVID-19 pandemic and the growing need for molecular testing, many laboratories have not been able to adequately assess the efficiency of the tests made available for use and they are using $\mathrm{Ct}$ value below 40 as positive diagnoses for SARS-CoV-2. We identified, by repeating two or more times the sample extraction with high $\mathrm{Ct}$, that these samples have low reproducibility, suggesting the need for patient return to completely repeat the US CDC test for greater diagnostic security. We identified that the low reproducibility of samples in the Ct range above 34 for US CDC primer sets could happen for 3 reasons: (i) cross contamination of the samples during processing; (ii) low viral load in the samples due to the final or initial stage of infection (iii) presence of low viral load close to the detection limit of the technique.

Few cases of reinfection have been reported in different countries around the world (Prado-Vivar et al. 2020, To et al. 2020, Van Elslande et al. 2020, Tillett et al. 2020). The reinfection data report a case of mild infection with low viral load and high $\mathrm{Ct}$ value followed by a period without positive serology for SARS-CoV-2 infection and a second infection with high viral load and severe symptoms and followed by serology positive (Prado-Vivar et al. 2020, Tillett et al. 2020). In view of the data in this study, we consider that the authors should exercise caution in stating cases of reinfection based on high $\mathrm{Ct}$ values in either of the two episodes reported in the same patient. In addition, a definitive study on humoral response demonstrated a robust long-term production of neutralizing antibodies against SARS-CoV-2 in patients infected only once (Wajnberg 
et al. 2020). Evidence of reinfection should take into account cases in which there was a clear viral load in both episodes and could rule out the presence of cross-contamination between samples during the analyzes, which could explain both the high $\mathrm{Ct}$ values between the samples and the genetic diversity observed. Then, any case report presented viral load below $\mathrm{Ct}$ value 30 in both episodes of infection should be considered reinfection (Prado-Vivar et al. 2020, To et al. 2020, Van Elslande et al. 2020, Tillett et al. 2020).

Together, our data show that both N1 and N2 sets of probes and primers can be used individually for the diagnosis of COVID-19. In addition, we found that the RT-qPCR technique involving US CDC primers should be used with caution in the diagnosis of patients whenever the $\mathrm{Ct}$ values are close to the detection limit established by each one laboratory services. We recommend that samples with $\mathrm{Ct}$ above the detection limit be re-extracted and reanalyzed by an alternative protocol and in cases of doubt, a new examination must be performed on the patient before the diagnosis can be released as positive. The data from this and study has an impact on the interpretation of future data about the COVID-19 pandemic and on the conduct of sample analysis using the $\mathrm{N}$ gene as a target.

\section{Contributors}

Conceived and designed the experiments R.C.K., L.P.R.V., J.B.L., T.A.S. Data collection: L.V.G.K., L.P.R.V., L.G.B., R.C.K., J.B.L., T.A.S; Analyzed the data: R.C.K., L.P.R.V., J.B.L. T.A.S.; Contributed materials/analysis tools: L.V.G.K, M.H.F.K, R.C.K., J.B.L., T.A.S.; Wrote the paper: J.B.L., T.A.S., R.C.K.

\section{Declaration of Interests}

All authors should disclose any type of conflict of interest during the development of the study. 


\section{Acknowledgment}

We thank the Secretariat of Epidemiological Surveillance of the city of Barreiras and the West Hospital for providing data on patients treated in the municipality. We also thank Rosilene, Iole and Marlan for technician support.

\section{References}

Ai T, Yang Z, Hou H, Zhan C, Chen C, Lv W, Tao Q, Sun Z, Xia L 2020. Correlation of Chest CT and RT-PCR Testing for Coronavirus Disease 2019 (COVID-19) in China: A Report of 1014 Cases. Radiology 296: E32-E40.

Candido DS, Claro IM, Jesus JG de, Souza WM, Moreira FRR, Dellicour S, Mellan TA, Pereira RHM, Sales FCS, Manuli ER, Thézé J, Almeida L, Menezes MT, Voloch CM, Fumagalli MJ, Coletti TM 2020. Evolution and epidemic spread of SARS-CoV-2 in Brazil. : 8.

Cariani L, Orena BS, Ambrogi F, Gambazza S, Maraschini A, Dodaro A, Oggioni M, Orlandi A, Pirrone A, Uceda Renteria S, Bernazzani M, Cantù AP, Ceriotti F, Lunghi G 2020. Time Length of Negativization and Cycle Threshold Values in 182 Healthcare Workers with Covid-19 in Milan, Italy: An Observational Cohort Study. Int. J. Environ. Res. Public. Health 17: 5313.

Centers for Disease Control and Prevention. 2019-novel coronavirus (2019-nCoV) realtime RT-PCR primer and probe information 2020.

Etievant S, Bal A, Escuret V, Brengel-Pesce K, Bouscambert M, Cheynet V, Generenaz L, Oriol G, Destras G, Billaud G, Josset L, Frobert E, Morfin F, Gaymard A 2020. Performance Assessment of SARS-CoV-2 PCR Assays Developed by WHO Referral Laboratories. J. Clin. Med. 9: 1871. 
Güçlü E, Koroglu M, Yürümez Y, Toptan H, Kose E, Güneysu F, Karabay O 2020.

Comparison of saliva and oro-nasopharyngeal swab sample in the molecular diagnosis of COVID-19. Rev. Assoc. Médica Bras. 66: 1116-1121.

Hallal PC, Hartwig FP, Horta BL, Silveira MF, Struchiner CJ, Vidaletti LP, Neumann NA, Pellanda LC, Dellagostin OA, Burattini MN, Victora GD, Menezes AMB, Barros FC, Barros AJD, Victora CG 2020. SARS-CoV-2 antibody prevalence in Brazil: results from two successive nationwide serological household surveys. Lancet Glob. Health 8: e1390-e1398.

Liu X, Feng J, Zhang Q, Guo D, Zhang L, Suo T, Hu W, Guo M, Wang X, Huang Z, Xiong Y, Chen G, Chen Y, Lan K 2020. Analytical comparisons of SARSCOV-2 detection by qRT-PCR and ddPCR with multiple primer/probe sets. Emerg. Microbes Infect. 9: 1175-1179.

Mathuria JP, Yadav R, Rajkumar 2020. Laboratory diagnosis of SARS-CoV-2 - A review of current methods. J. Infect. Public Health 13: 901-905.

on behalf of the SARS-CoV-2 Foch Hospital study group, Farfour E, Lesprit P, Visseaux B, Pascreau T, Jolly E, Houhou N, Mazaux L, Asso-Bonnet M, Vasse M 2020. The Allplex 2019-nCoV (Seegene) assay: which performances are for SARS-CoV-2 infection diagnosis? Eur. J. Clin. Microbiol. Infect. Dis. 39: 1997-2000.

Pizzol JLD, Hora VP da, Reis AJ, Vianna J, Ramis I, Groll A von, Silva PA da 2020. Laboratory diagnosis for Covid-19: A mini-review. Rev. Soc. Bras. Med. Trop. 53: e20200451. 
Prado-Vivar B, Becerra-Wong M, Guadalupe JJ, Marquez S, Gutierrez B, Rojas-Silva

P, Grunauer M, Trueba G, Barragan V, Cardenas P 2020. COVID-19 Re-

Infection by a Phylogenetically Distinct SARS-CoV-2 Variant, First Confirmed

Event in South America. SSRN Electron. J.

Tillett RL, Sevinsky JR, Hartley PD, Kerwin H, Crawford N, Gorzalski A, Laverdure C, Verma SC, Rossetto CC, Jackson D, Farrell MJ, Van Hooser S, Pandori M 2020.

Genomic evidence for reinfection with SARS-CoV-2: a case study. Lancet

Infect. Dis.: S1473309920307647.

To KK-W, Hung IF-N, Ip JD, Chu AW-H, Chan W-M, Tam AR, Fong CH-Y, Yuan S, Tsoi H-W, Ng AC-K, Lee LL-Y, Wan P, Tso EY-K, To W-K, Tsang DN-C, Chan K-H, Huang J-D, Kok K-H, Cheng VC-C, Yuen K-Y 2020. Coronavirus Disease 2019 (COVID-19) Re-infection by a Phylogenetically Distinct Severe Acute Respiratory Syndrome Coronavirus 2 Strain Confirmed by Whole Genome Sequencing. Clin. Infect. Dis.: ciaa1275.

Van Elslande J, Vermeersch P, Vandervoort K, Wawina-Bokalanga T, Vanmechelen B, Wollants E, Laenen L, André E, Van Ranst M, Lagrou K, Maes P 2020.

Symptomatic SARS-CoV-2 reinfection by a phylogenetically distinct strain. Clin. Infect. Dis.: ciaa1330.

Vogels CBF, Brito AF, Wyllie AL, Fauver JR, Ott IM, Kalinich CC, Petrone ME, Casanovas-Massana A, Muenker MC, Moore AJ, Klein J, Lu P, Lu-Culligan A, Jiang X, Kim DJ, Kudo E, Mao T, Moriyama M, Oh JE, Park A, Silva J, Song E, Takehashi T, Taura M, Tokuyama M, Venkataraman A, Weizman O-E, Wong P, Yang Y, Cheemarla NR, White E, Lapidus S, Earnest R, Geng B, Vijayakumar P, Odio C, Fournier J, Bermejo S, Farhadian S, Dela Cruz C, 
Iwasaki A, Ko AI, Landry M-L, Foxman EF, Grubaugh ND 2020. Analytical sensitivity and efficiency comparisons of SARS-COV-2 qRT-PCR primer-probe sets. Infectious Diseases (except HIV/AIDS).

Wajnberg A, Amanat F, Firpo A, Altman DR, Bailey MJ, Mansour M, McMahon M, Meade P, Mendu DR, Muellers K, Stadlbauer D, Stone K, Strohmeier S, Simon V, Aberg J, Reich DL, Krammer F, Cordon-Cardo C 2020. Robust neutralizing antibodies to SARS-CoV-2 infection persist for months. Science: eabd7728.

Wyllie AL, Fournier J, Casanovas-Massana A, Campbell M, Tokuyama M, Vijayakumar P, Warren JL, Geng B, Muenker MC, Moore AJ, Vogels CBF, Petrone ME, Ott IM, Lu P, Venkataraman A, Lu-Culligan A, Klein J, Earnest R, Simonov M, Datta R, Handoko R, Naushad N, Sewanan LR, Valdez J, White EB, Lapidus S, Kalinich CC, Jiang X, Kim DJ, Kudo E, Linehan M, Mao T, Moriyama M, Oh JE, Park A, Silva J, Song E, Takahashi T, Taura M, Weizman O-E, Wong P, Yang Y, Bermejo S, Odio CD, Omer SB, Dela Cruz CS, Farhadian S, Martinello RA, Iwasaki A, Grubaugh ND, Ko AI 2020. Saliva or Nasopharyngeal Swab Specimens for Detection of SARS-CoV-2. N. Engl. J. Med. 383: 1283-1286. 
medRxiv preprint doi: https://doi.org/10.1101/2020.12.06.20244905; this version posted December 8, 2020. The copyright holder for this preprint (which was not certified by peer review) is the author/funder, who has granted medRxiv a license to display the preprint in perpetuity.

It is made available under a CC-BY-NC-ND 4.0 International license .

Table 1. N1 versus N2 fitness in SARS-CoV-2 detection in population

\begin{tabular}{|c|c|c|c|c|}
\hline \multirow{2}{*}{ Ct value group } & \multicolumn{2}{|c|}{ Target } & \multicolumn{2}{|l|}{ Specimens } \\
\hline & N1 \% & N2\% & Sputum \% & Swabs \% \\
\hline Ct undetermined & 48,0 & 48,0 & 47,5 & 48,1 \\
\hline $\mathrm{Ct}<\mathbf{3 0}$ & 25,3 & 25,3 & 31,8 & 23,9 \\
\hline $30<$ N1 e N2 $<34$ & 5,4 & 5,4 & 4,5 & 5,6 \\
\hline $\mathrm{Ct}>34$ & 10,9 & 10,9 & 9,5 & 11,2 \\
\hline Ct failure ${ }^{* *}$ & 5,1 & 5,3 & 6,7 & 11,2 \\
\hline
\end{tabular}

*Data from 1029 different patient samples.

**Ct failure were just one target presents amplification 


\section{Figure 1. Comparison between N1 and N2 Ct values during SARS-CoV-2 detection}

in patient samples. Data on the graphs indicate $\mathrm{N} 1$ and $\mathrm{N} 2 \mathrm{Ct}$ values comparison for each patient samples of (A) swab and (B) sputum by linear regression (left panels) or paired analysis (right panels). $\mathrm{p}$ value $<0.0001$ for linear regression and paired t test $\mathrm{p}<$ 0.9483.

\section{Figure 2. Checking N1/N2 accuracy by $\mathrm{Ct}$ value using RT-PCR and}

polyacrylamide gel. Patient samples were completely reanalyzed to check the accuracy to $\mathrm{N} 1$ and $\mathrm{N} 2$ gene targets. (A) Contingency graphs display percentages of agreement between two testing in different cycle threshold (Ct) groups. Representative (B) polyacrylamide gel and (C) amplification plots in log (left panel) and linear (right panel) representations. Arrowheads indicate nonspecific amplicons. Und. - undetermined Ct.

Figure 3. Double testing analysis of high $\mathrm{Ct}$ value samples of patients. (A) Patient samples were completely reanalyzed after new patient's testing until six days after first test. Blue dots indicate reduction and red dots indicate an increase of $\mathrm{Ct}$ value after second test. Red dashed line indicates the US CDC cut off to positives samples. (B) A Receiver Operator Characteristics (ROC) curve analysis was performed to assess the sensibility and specificity in the comparison between double positive samples and just first positive sample (presumptive negative). AUC: Area Under Curve. 
A

Swab

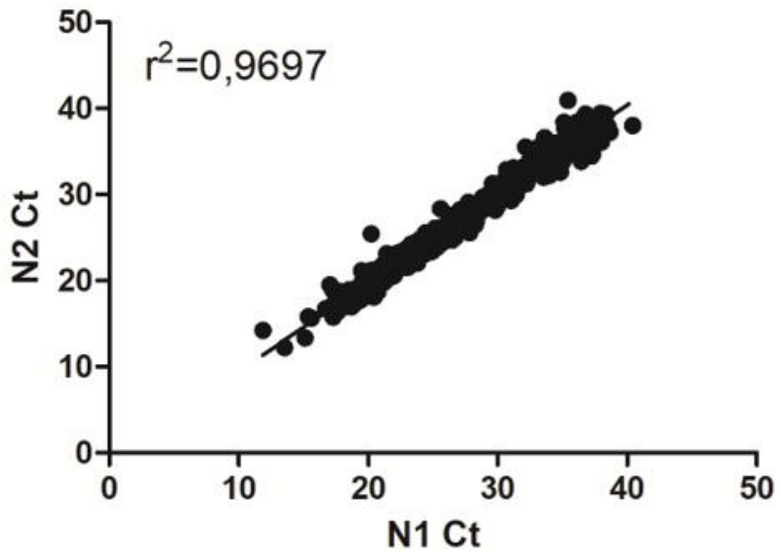

Sputum

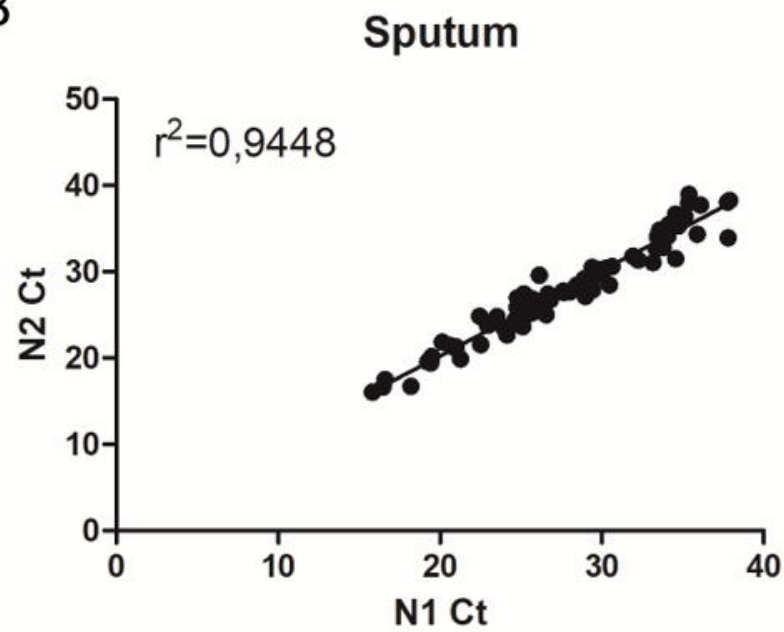

B
Swab Pairm ent

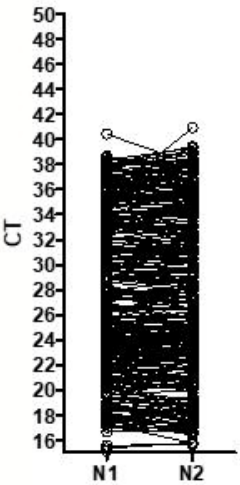

Sputum Pairment

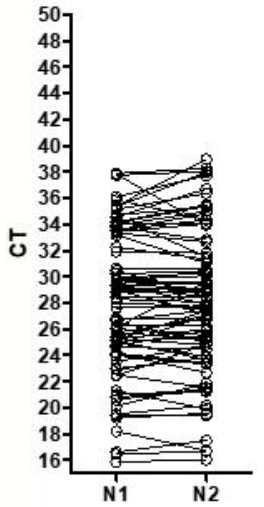


A

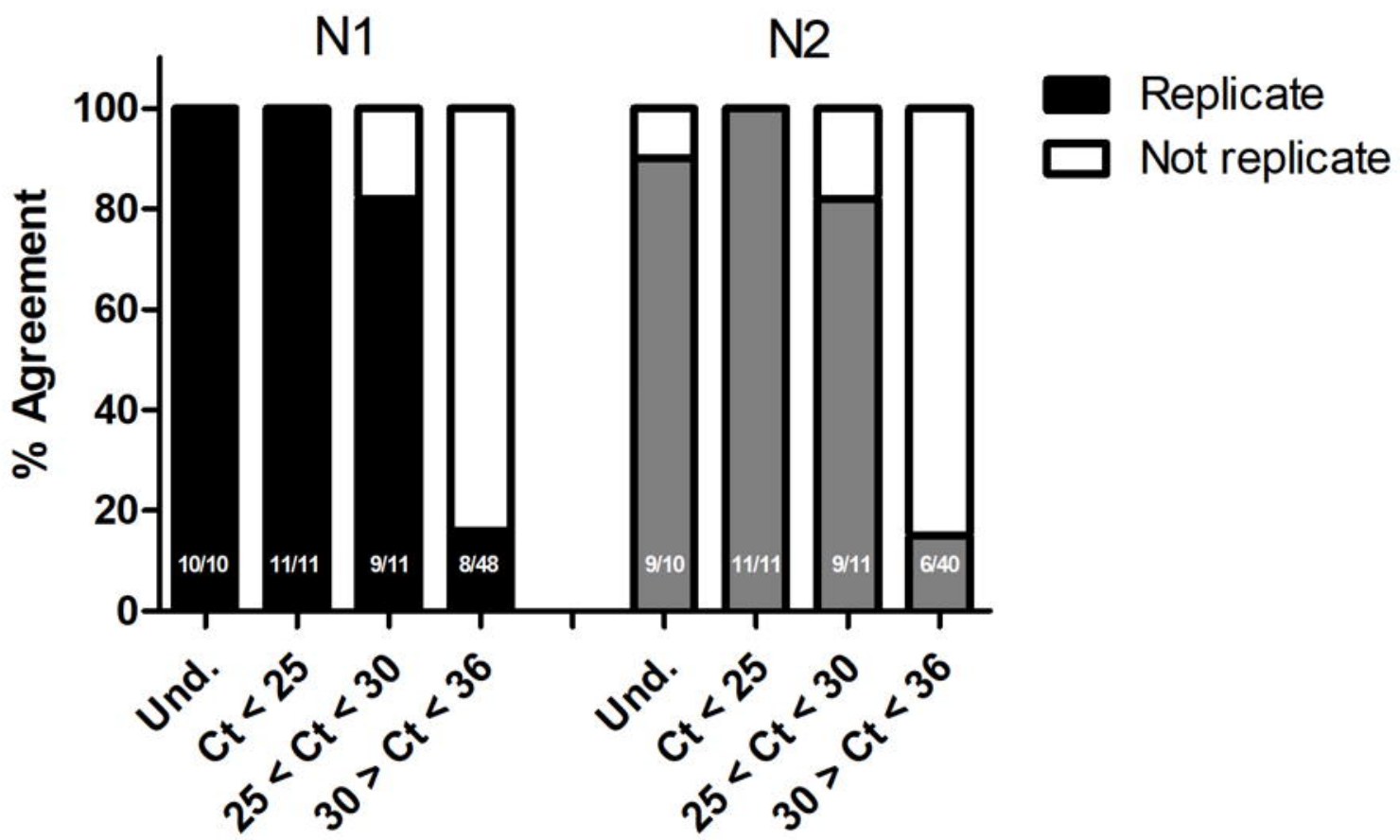

B

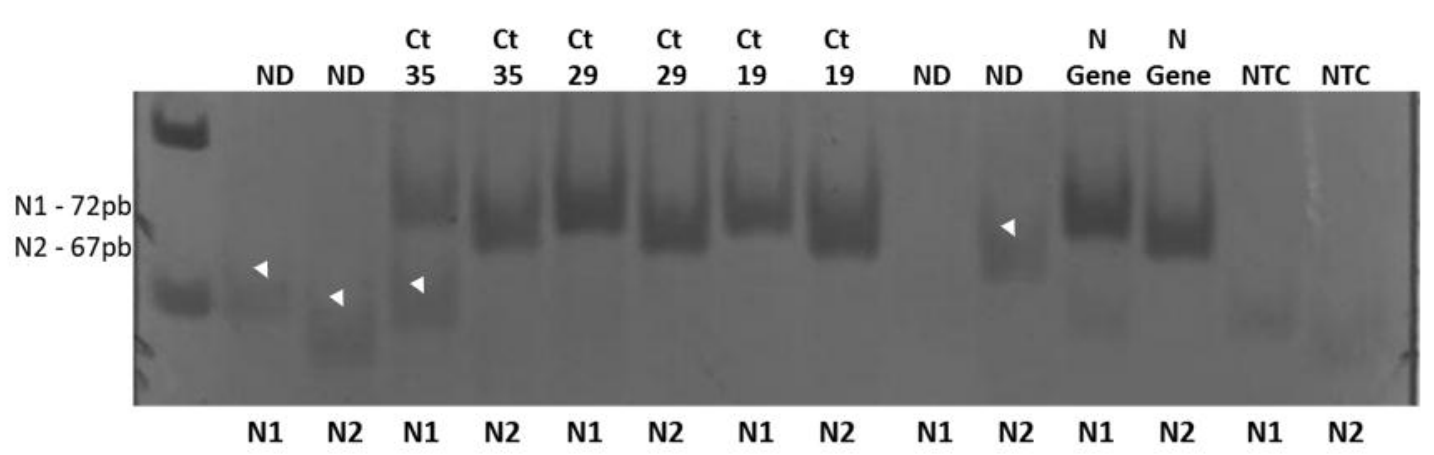

C
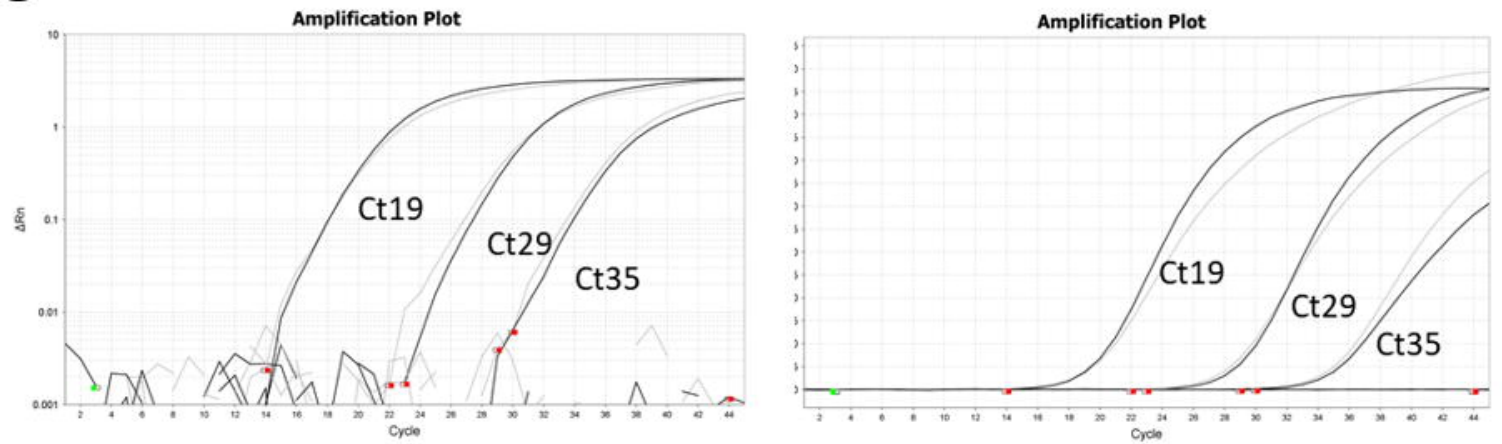
A

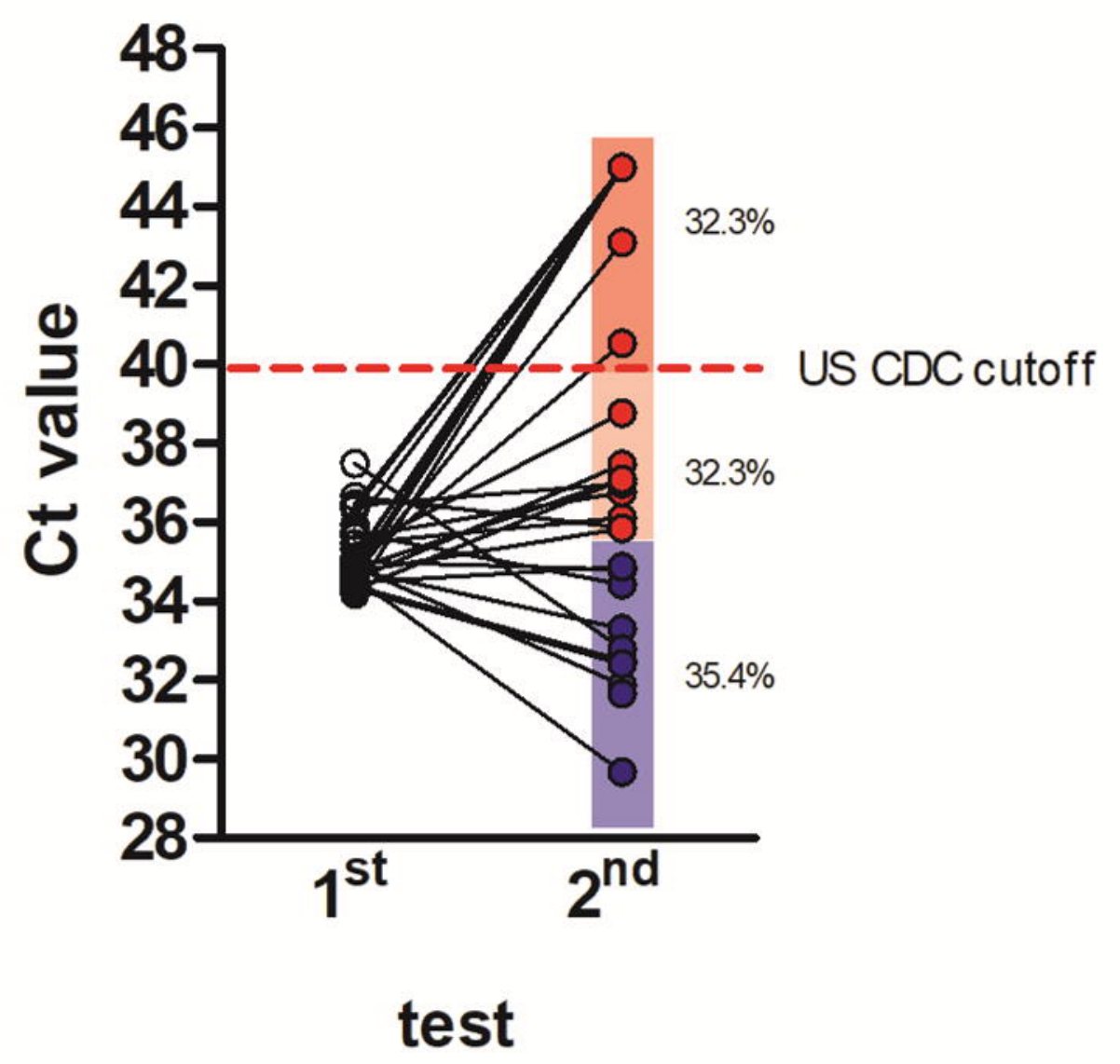

B

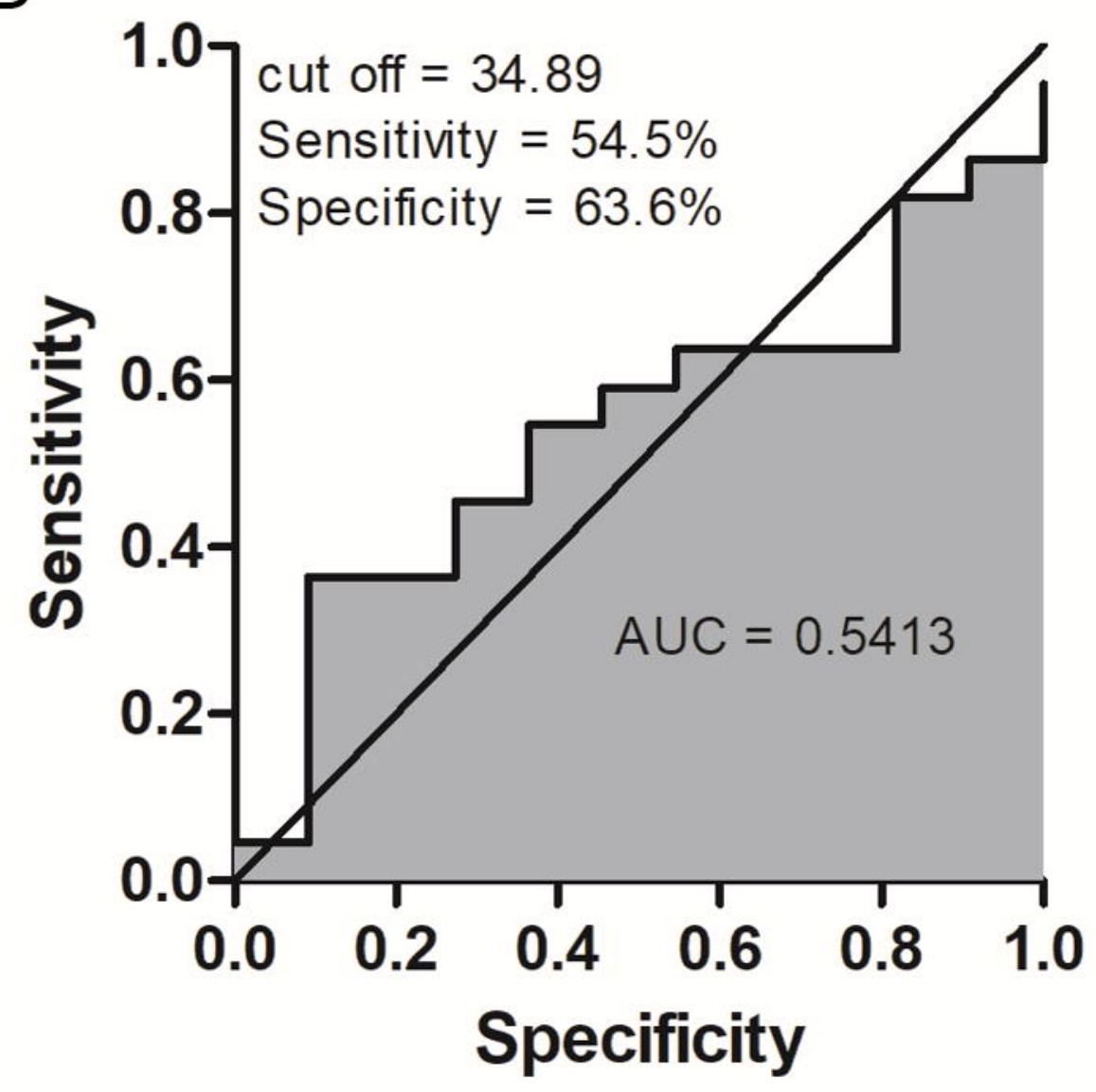

